Natalia Chuvasova

Kryvyi Rih State Pedagogical University

\title{
METHODOLOGICAL APPROACH TO THE RESEARCH OF THE PROBLEM OF FUTURE CHEMISTRY AND BIOLOGY TEACHERS' CREATIVE POTENTIAL DEVELOPMENT IN HIGHER EDUCATIONAL ESTABLISHMENTS
}

In the article on the basis of the pedagogical theory and practice analyses there were investigated and discovered the opportunities of the methodological approach to the research of the problem of future chemistry and biology teachers' creative potential development in the process of specialist training in the higher educational establishments. It is declared that a particular way reference enables to determinate the teaching activities strategy, the lines of approach, to explain the project conception of the developing model of the researched phenomenon. It has been investigated that the paradigmatic approach usage, being realized through the system of such approaches: system-practical, person-centered, competent, dialogical which compose methodological basis of the problem investigation, just provide a means of system development of future chemistry and biology teachers' creative potential.

Keywords: approach, future chemistry and biology teachers' creative potential development.

\section{Introduction}

Under the condition of the industrial society the role of higher education in the society functioning and in man's life has been changed essentially: the high rate of scientific and practical mankind knowledge accumulation, the complicacy of all kinds of man's activities set much higher conditions to the level of specialist training with the diploma of higher educational establishments compared to the previous practice. Firstly, this is reflected in proficient higher level of knowledge use that will help future chemistry or biology teacher to fulfill effective professional implementation; secondly, in qualitative deeper and system acquisition variety of skills, technologies and strategies of cognitive and practical activity; thirdly, in motivation training to individual study which rise in arms and from the sphere of «intellectually» advanced merge into something of minimal necessity as a result of rapid alternation in 


\section{Psychological and pedagogical problems of modern specialist formation}

professional and social spheres. The scientific literature analyses claims that modern teacher's creative potential is a very important characteristics of the professionalism, as well as a multiplex and dynamic phenomenon. The creative potential is connected with the search of some new paradigm attitude and methodological approaches, which characterize the pedagogical reality, its methodological basis without which one cannot reach the effective research problem solution.

\section{Materials and methods}

For the achievement of the objective, challenges implementation and hypothesis proof there was used such complex of methods: analysis, synthesis and philosophic psychologically-pedagogical systemization and methodical research, inquiry (filling a form, testing, discussion), pedagogical experiment for discovering of results rating of future chemistry and biology teachers' creative potential development in higher educational establishments.

\section{Discussion}

Category «approach» is used in the pedagogical practice as a practical commitment of a teacher on «certain totality of interrelated concepts, ideas and methods of pedagogical activity» (O. Stepanov and L. Luzina [3, p. 83]). L. Kondrashova considers the concept «approach» in scientific literature is interpreted as an orientation on those or other aspects of student's cognitive activity, the process of personality individuality becoming. Any approach unites initial concepts, principles and technologies of studies [1].

For different students is characteristic for different degree or intensity in the active cognition. A student's degree display of creative potential in the educational process is a dynamic, constantly new index. For realization of our research we must know the initial level of the creative potential development.

Experimental work was conducted on the basis of the articles of the chemical-biological cycle, because during the process of chemical processes analysis, solving chemical problems, implementation of laboratory and practical work from the courses of biology, chemistry and other studies, students get used to the valuable argumentation of their actions. It allows to avoid groundless generalizations, analogies, keep the formally - logical chart of reasoning, develop the ability to work in a necessary rate to all members of the group, carry out self-control.

During the ascertaining experiment the level of creative potential development of future chemistry and biology teachers was found out. 53,2\% students have a low level of this difficult personality education, $41,9 \%$ have middle level, $5 \%$ have high level. 
The analysis of the received facts allows to talk about unefficiency of traditional studies. Paradigm approach to the lessons organization does not get the proper attention which confirms supposition about the absence of the focused effort on future teachers of chemistry and biology's creative development. The ascertaining experiment discovered that essence of development of creative potential is understood far not by all teachers (and if it is understood, it's very approximately) that is why it is not used.

The obtained information gives the opportunity to suggest that at traditional studies there can be seen spontaneous development of creative potential of future teachers of chemistry and biology, that does not provide high - quality studies. All process of studies carried intuitional spontaneous character, self-organization and self-control were fragmentary.

One need to search the reasons of such circumstances not only in social terms but also in genesial system of studies. Methodical and subject content side of the visited lessons were not aimed at the students' creative potential development, providing of creative atmosphere which stimulates the students' creative approach to the solution of creative cognitive tasks. The focused effort of teachers in relation to the development of students' positive motivation and cognitive interest was absent.

The place of student in the role of a passive listener, a simple performer of teacher's will, when he is forced mainly to reproducing the mastered, leads to the decline of creative potential's level, low degree of getting creative knowledge and skills, the subject specific of terminology. Teachers pay not enough attention to the development of students' creative potential, to its emotionality, expressiveness, sequence, conviction that leads to the decline of creative potential level.

Paying attention to the fact that in pedagogical practice not full scope of paradigm approach is used by students during studies, we made attempt to find out the possibilities for development of creative potential future teachers of chemistry and biology.

Today the problem of development of creative potential is fully described with system - practical approach, which is based on theoretical positions of A. Asmolov, L. Vigotskiy, P. Galperin, V. Davidov, D. Elkonin, A. Leontiev.

Using the system - practical approach in the process of preparation of future chemistry and biology teacher the studies were organized as an active process of mastering of different types of professional activity. At the same time the purpose of studies included not only the acquiring of knowledge and abilities but also forming practical skills (competence), which confirm the profession selected. Exactly this skills set afterwards will come forward as a basic criterion of competence of future of chemistry and biology teacher. 


\section{Psychological and pedagogical problems of modern specialist formation}

The system - practical approach presented the variety of variants of the development of the the same preparation system of future chemistry and biology teacher. In relation to higher professional education this approach excludes the presence of the unique and universal system of professional preparation for all specialities. The research of process of development of future chemistry and biology teacher's creative potential demands bringing in such categories, as «system», «unit», «part», «relation», «structure», which represent an ambiguousness and dynamic of researched fenomena. The components of this difficult personality education of future chemistry and biology teacher were analysed through the prism of integral approach, as the main function of each component of creative potential is work for «the unit».

From the point of view of system - practical approach, the main sense of any pedagogical theory consisted in the exposure of integral properties of every component of the system. At every level of preparation of competent chemistry and biology teacher of we dealt with integral personality and in the total got a graduate who not only obtained a university diploma, but also owned qualified characteristics of a chemistry and biology teacher. Without regard to that a graduate has the opportunity to apply the obtained education to practice, the marked levels are the components of the integral multilevel system of higher professional education, because they are interrelated.

The basis of personality - oriented approach in studies comprised the conceptual positions of psychologists about the dominant role of activity in intercourse and forming of a personality. Taking into account that fact, the educational process was directed not only on knowledge mastering, but also on the methods of mastering and thinking process, on the development of cognitive forces and creative capabilities of future of chemistry and biology teachers. We considered that in accordance with that there must be a student in the centre of studies, his aims, reasons, interests, inclinations, the level of his proficiency and capabilities.

Competency - based approach, in obedience to V. Serikov's position [2, p. 112], comprises the progress of culturological and practical approaches to the content of education and at the same time refreshes the pragmatic, effective component of the professional culture. A competence similarly comes forward as personality quality which is based on knowledge, intellectually and personality predefined social - professional description of a man.

For preparation of chemistry and biology teacher presented a most valued was practical - oriented component of competency - based approach, as it strengthens the actuality of professional education, promotes its quality and results efficiency. Strengthening of practical essence of studies resulted in displacement of accents on character of actions 
conducted by the future of chemistry and biology teacher. It similarly influenced on the integration of professional and personality (especially, motivational) structures of specialist.

It is clear, that dialogic approach which today is intensively developed in pedagogical science comes into a large notice in methodological basis of development of creative potential of future of chemistry and biology teachers.

The questions of the effective use of linguistic activity are examined: linguistic activity as index of development of subject activity (G. Schukina); pedagogical organization of linguistic activity is in an educational process (A. Ksenofontova); connection of language and thought (L. Vigotskiy); the practical approach to the language (O. M. Leontiev, O. O. Leontiev).

The creative potential of future of chemistry and biology teachers is an attribute property of any personality, inseparable component of its structure. If student's creative potential does not develop, he stops feeling his or her creative personality. But creative potential does not develop by itself. It can remain at a low level in every student, if in the process of studies in higher educational establishment he was not plugged into creative process, did not obtain experience of some active creative activity. The search of more detailed approaches to the creative potential development generates the necessity of lining up an educational process so, that not a single talented personality went out, that the active cognitive capabilities of every student could be realized to the full extent. At dialogic approach character of creative activity and position of student differ considerably. During organization of educational process on principles of dialogic approach creative potential rises to the higher level, students are ready for independent work, display of initiative, creativity. Have the opportunities to be equal in rights students, to influence on character of creative activity, feel responsibility for themselves and for the result. For dialogic approach the peculiar personal character of creative activity is characteristic of, as well as display of the attitude towards the obtained knowledge, their usage as the instrument of solution of creative practical tasks.

The dialogic approach allowed to develop intercourse skills in different situations with surrounding people, ability to listen to others, chose the reference point, capacities for self - realization, to self - knowledge, the situation of favourable creative display and development of individual capabilities was created.

The teachers activity in groups, where there prevailed students with the low level of creative potential, were lead for the creation of some special emotional lesson atmosphere, which pushed the future chemistry and biology teachers to plugging in a creative educational process. So there was a chain: state of students' comfort, absence of fear, and then sense of 


\section{Psychological and pedagogical problems of modern specialist formation}

confidence, readiness and expectation of meeting, with a teacher, expectation of a lesson with creative activity. Psychological pre-conditions were created for student's passing to the higher level of development of creative potential.

During the forming experiment the degree of development of creative potential was studied. Diagnostic materials which enabled to find out the level of development of creative potential of future of chemistry and biology teachers in the process of professional preparation of pedagogical university were developed.

The results of research showed that realization of the offered experimental program had provided the improvement of components state of the probed creative potential from low to the middle and high levels in experimental groups.

As it can be seen, the first level (the high one) of development of creative potential is owned by $29,5 \%$ students, by the second level (the middle one) $-61,3 \%$, by the third level (the low one) $-9,2 \%$.

The obtained facts confirm, that students become more mobile, unchained, active, they are able to conduct a dialog, capable to offer different ways and methods of solutions of creative educational tasks, prove their viewpoint and methods of the task implementation, are ready for a discussion, defend their own vision of educational problem, and its creative solution. Introduction of the paradigm approach of studies as a base principle of planning and conducting of lessons on his basis considerably extended possibilities for studies, development and growth of creative potential of future chemistry and biology teachers. Students developed their skills of the active listening, choosing the main idea, argumentative defending their own viewpoint, their creative potential increased to a higher level. Students developed their creative skills for solution of various problems, that enabled to find an output in any situation, creatively to solve the tasks.

The realization of the research - experimental program in experimental groups reflected positively at the level of development of creative potential of future chemistry and biology teachers. On the basis of the conducted experiments we can state that the most favorable situation for awakening and development of creative potential of future chemistry and biology teachers in the process of professional preparation in the pedagogical university involves providing of positive motivation development, proof cognitive interests to creative activity, cognitive necessity; providing self-management of studies process and successful forming of the knowledge system, successful applying of the intellectual abilities, related to processing of the gained information, by abilities of lingually - mental activity; pedagogical educational environment, collaboration and co-work of a teacher and students for providing the 
success situation, psychological comfort of every student, stimulation of self-perfection, self-criticism, confidence in themselves are necessary for development of creative potential of future chemistry and biology teachers.

Introduction of the paradigm approach to the development of creative potential of future chemistry and biology teachers extends the possibilities for studies, development and increase of student's creative personality. For students the creative approach develops the solution of various problems, that gives an opportunity to compensate the effect of aging of the scientific information gained at the university. Every lesson must create a favourable situation for the display of students' creativity, forming the skills of making decision and readiness to the creative personal responsibility for their result.

\section{Conclusions}

Combining in the educational process various approaches and principles provides gaining the main aim, that is the preparation of competitive specialist, able to creative pedagogical activity at the level of world standards, ready to the permanent pedagogical development, social and pedagogical mobility. A clearness, logic, scientific validity of conceptual positions, predetermines efficiency of the development of creative potential of future of chemistry and biology teachers, as the important description of their professionalism.

\section{References}

1. Kondrashova, L. V. (2014). Pedagogika vishei shkoly: problemy, poiski, resheniya [Pedagogics of higher education: problems, searches, solutions]. Kryvyi Rih: Bohdan Chmelnitskiy ChNU. (in Russian)

2. Serikov, V. V. (1998). Lichnostno orientirovannoe obrazovaniye: poisk novoy paradigmy [Personally oriented education: the search for a new paradigm]. Moscow: Znanie. (in Russian)

3. Stepanov, E. N., \& Luzina, L. M. (2002). Pedagogu o sovremennyh podhodah $i$ kontseptsiyah vospitaniya [Teachers about modern approaches and concepts of education]. Moscow: TS Sphera. (in Russian)

Наталія Чувасова. Методологічні підходи до дослідження проблеми розвитку творчого потенціалу майбутніх учителів хімії та біології у вищих навчальних закладах.

У статті на основі аналізу педагогічної теоріі $i$ практики проаналізовані та розкриті можливості методологічних підходів до дослідження проблеми розвитку творчого потенціалу майбутніх учителів хімії та біології у процесі фахової підготовки у вищих 


\section{Psychological and pedagogical problems of modern specialist formation}

навчальних закладах. Наголошено, щзо орієнтація на той чи інший підхід дозволяє визначити стратегію педагогічної діяльності, иляхи та способи вирішення досліджуваної проблеми, обгрунтувати проектування моделі формування досліджуваного феномена. Досліджено, що використання парадигмального підходу реалізується через систему підходів: системно-діяльнісного, особистісноорієнтованого, компетентнісного, діалогічного, які складають методологічну основу дослідження проблеми й припускають розробку системи розвитку творчого потенціалу майбутніх учителів хімії та біології.

Ключові слова: підхід, розвиток творчого потенціалу майбутніх учителів хімії та біологї.

Natalia Chuvasova. Metodyczne podejście do badań problemów rozwoju potencjału twórczego przyszłych nauczycieli chemii i biologii w szkolnictwie wyższym.

Na podstawie analizy teorii i praktyki pedagogicznej ujawniono możliwość podejścia metodologicznego do studiowania problemu twórczego potencjatu przysztych nauczycieli chemii $i$ biologii, $w$ trakcie szkolenia $w$ wyższych instytucjach edukacyjnych. Podkreślić należy, że skupienie się na konkretnym podejściu do określenia strategii działań edukacyjnych, sposobów i środków rozwiąania badanego problemu uzasadnia model konstrukcyjny analizowanego zjawiska. Zbadano, że stosowanie paradygmatycznego podejścia realizowanego poprzez: aktywność systemowa, zorientowanie na osobowość, kompetencje stanowia metodologiczna podstawe do badań problemów rozwoju potencjatu twórczego przysztych nauczycieli chemii i biologii.

Stowa kluczowe: podejście, rozwój twórczego potencjatu przyszlych nauczycieli chemii i biologii.

Received 10.08.2017

\section{Information about the author:}

Chuvasova Natalia - Doctor of Philosophy in Pedagogy, Associate Professor at the Department of Chemistry and Teaching Techniques, Kryvyi Rih State Pedagogical University. 